INTERDISCIPLINARIA ARCHAEOLOGICA NATURAL SCIENCES IN ARCHAEOLOGY

A look at the region

\title{
Archaeological Centre Olomouc - Institutional History
}

\author{
Jaroslav Peškaa ${ }^{a}$ Lukáš Šín ${ }^{\text {** }}$ \\ ${ }^{a}$ Archaeological Centre Olomouc, U Hradiska 42/6, 77900 Olomouc, Czech Republic
}

\section{A RTICLE INFO}

\section{Article history:}

Received: $21^{\text {st }}$ August 2016

Accepted: $28^{\text {th }}$ December 2016

Key words:

Archaeological Centre Olomouc

archaeological excavation

cultural heritage

interdisciplinarity

Olomouc region

\begin{abstract}
A B S T R A C T
The care of archaeological monuments in the region of central Moravia is presently fulfilled through the activities of the Archaeological Centre Olomouc. The centre was founded on January $1^{\text {st }}, 2003$ with the goal of saving the important parts of a disappearing cultural heritage. It thus takes care of archaeological rescue excavations caused by various construction works. It records and documents archaeological actions, finds and findspots, stores the finds during their technical and professional processing, and then presents the excavation results to professionals along with the non-professional public. It also cooperates with other archaeological or cultural organizations and academic institutions. Research activities are also focused on the interpretation of particular historical events in individual societies using the data obtained by archaeological excavation. The centre applies the same theoretical approach to all the many other disciplines it incorporates in its work. Using the methods of several disciplines enables the integration of data and research cooperation in studies of settlement in particular regions in the past. The criteria for such interdisciplinary research are described in this article. The Archaeological Centre Olomouc, therefore, offers the creation of a platform for interdisciplinary cooperation between experts from various disciplines that concerns direct cooperation in field research and the modelling of reconstruction procedures involving settlement and funerary activities.
\end{abstract}

\section{Introduction - institutional history}

The Archaeological Centre Olomouc (ACO), the publisher of the IANSA Journal, was founded on $1^{\text {st }}$ January 2003. It is an allowance organization of the Olomouc Region, which acts as a specialized archaeological institution of this administrative territorial unit (Figure 1). Until the date of its foundation, in the years 1995-1998 the ACO acted as an organization titled the Institute of Archaeological Heritage Olomouc, and in the years 1999-2002 it was known as the Archaeological Centre of the Regional Museum in Olomouc. ACO takes an active part in the protection and salvation of movable and immovable archaeological monuments with the Olomouc Region and, where appropriate, in other territories as well. It carries out development-led archaeological excavations as well as rescue excavations induced by construction or any other earthworks. It records and documents archaeological actions, finds and findspots, stores finds during their technical

*Corresponding author. E-mail: sin@ac-olomouc.cz and professional processing, presents the excavation results to professionals as well as the non-professional public, participates in educational and methodology activities in the field of archaeology, and cooperates with other archaeological institutions and cultural organizations. Since 2003, ACO has carried out 375 archaeological rescue excavations and more than a thousand archaeological watching briefs at various construction works and actions (Figures 2, 3). These archaeological excavations yielded more than one million find items which were treated in the ACO laboratory (Figure 4). Individual archaeological excavations were documented by relevant excavation reports (185 issues).

\section{Activities, Projects and Cooperation with associated Institutes and Societies}

ACO professional workers published more than 300 scholarly and research articles and papers in many domestic and foreign periodicals, collected volumes and 


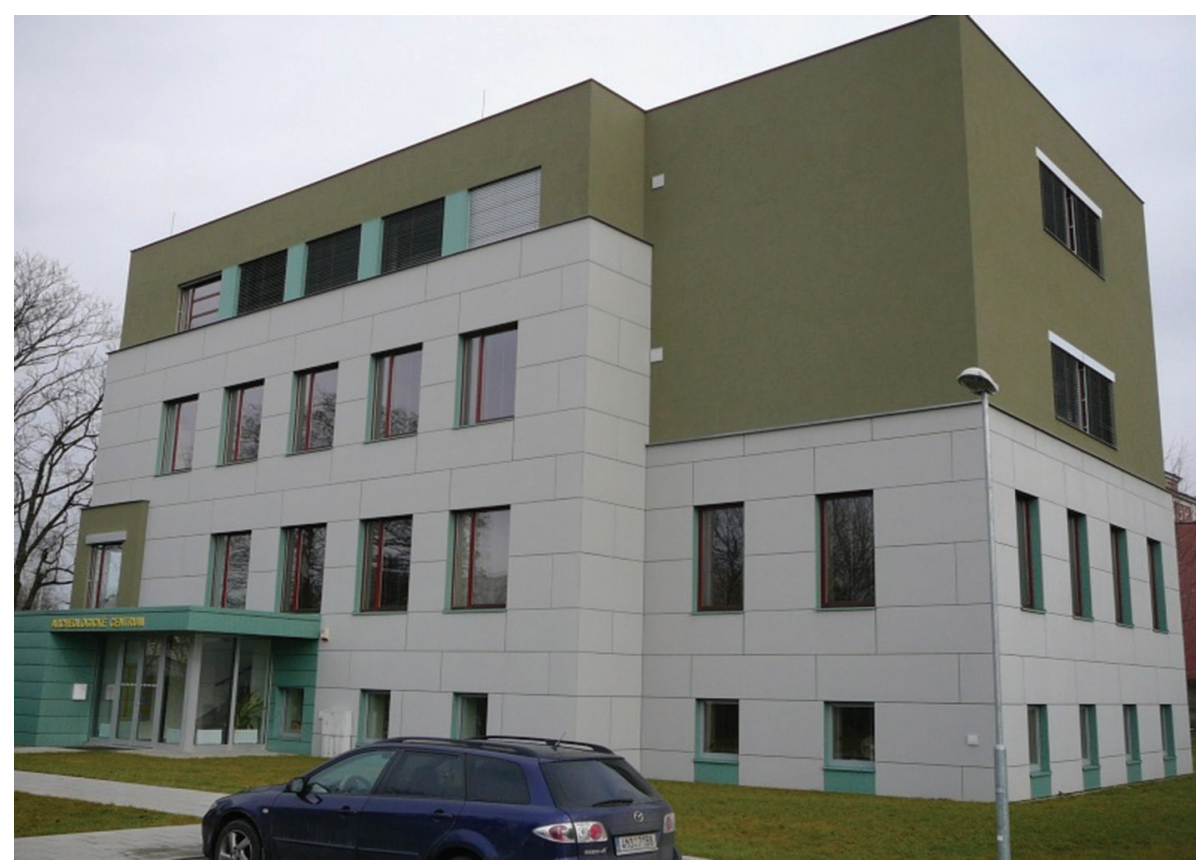

Figure 1. Archaeological Centre Olomouc, Main building. Photo: M. Bém.

monographs. They are the authors or co-authors of many publications, often acting as editors (Archeologické zrcadlení/Archaeological Reflections, Dědictví věků, Protoúnětické pohřebiště z Pavlova) or co-publishers, as well as the outputs of projects accomplished in cooperation with other institutions in our country and abroad (Popelnicová pole a doba halštatská, České Budějovice 2004; PANTA RHEI Studies on the Chronology and Cultural Development of South-Eastern and Central Europe in Earlier Prehistory, Bratislava 2010; Archaeology and Airborne Laser Scanning of the Landscape, Plzen 2013). Besides the IANSA Journal, ACO also issues a regular series of specialized publications which mainly present the results of excavations in the parent region. Among these are Ročenka Archeologického centra Olomouc, the monographic series Archeologiae Regionalis Fontes (ARF), and volumes about significant archaeological sites or topics Archeologické památky střední Moravy (APSM). Information about the current activities of ACO is published on the website www.ac-olomouc.cz. The institution acts as applicant or co-applicant in many projects of international impact. Among the most important ones are: Metal Corrosion Products in Archaeology: Complex Approach - Czech Science Foundation; A Burial Ground of the Bell Beaker Culture on the Motorway D1 Vyškov-Mořice

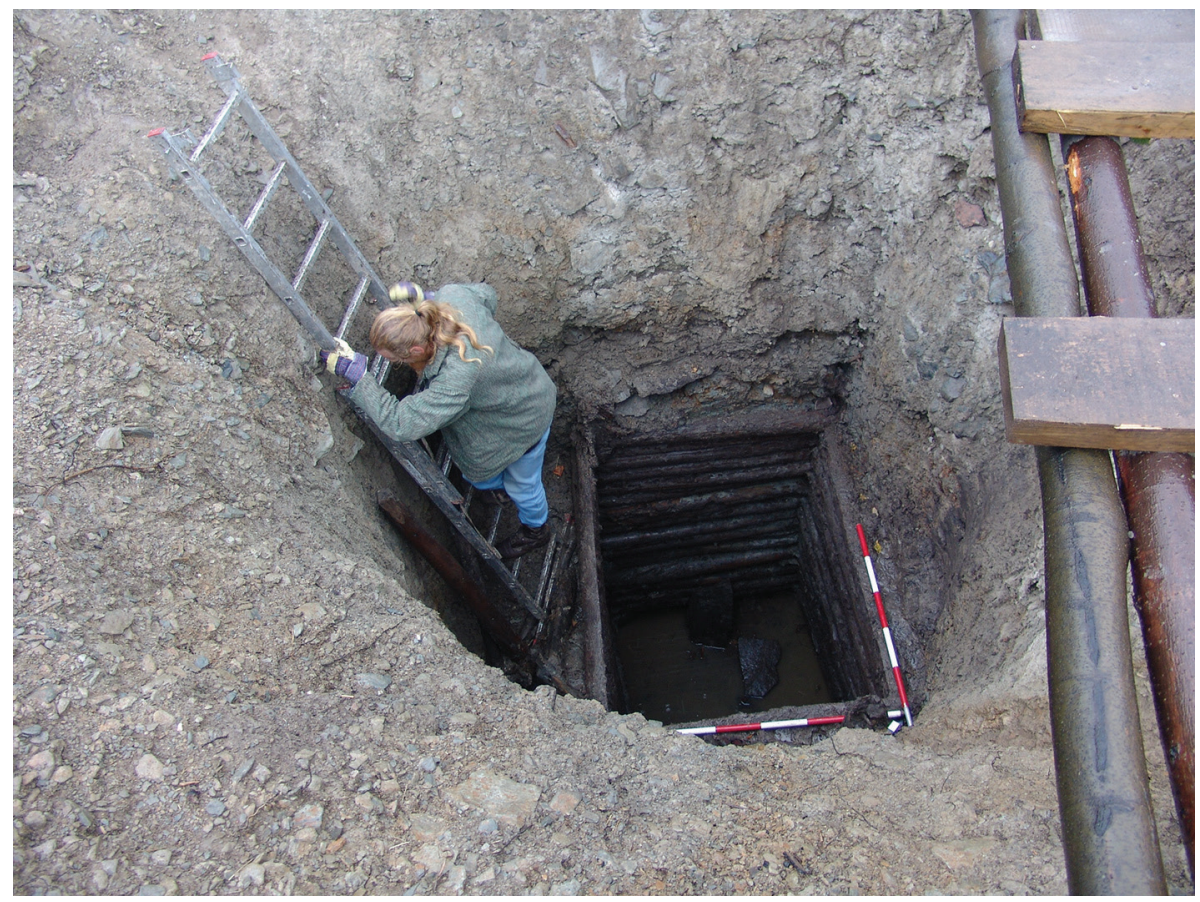

Figure 2. Exploration of medieval well, Tepenec castle, site Jívová - Tepenec (dist. Olomouc). Photo: V. Vránová. 
Figure 3. Preparation of skeletal burial, site Majetín, Náves street (dist. Olomouc). Photo: J. Vrána.

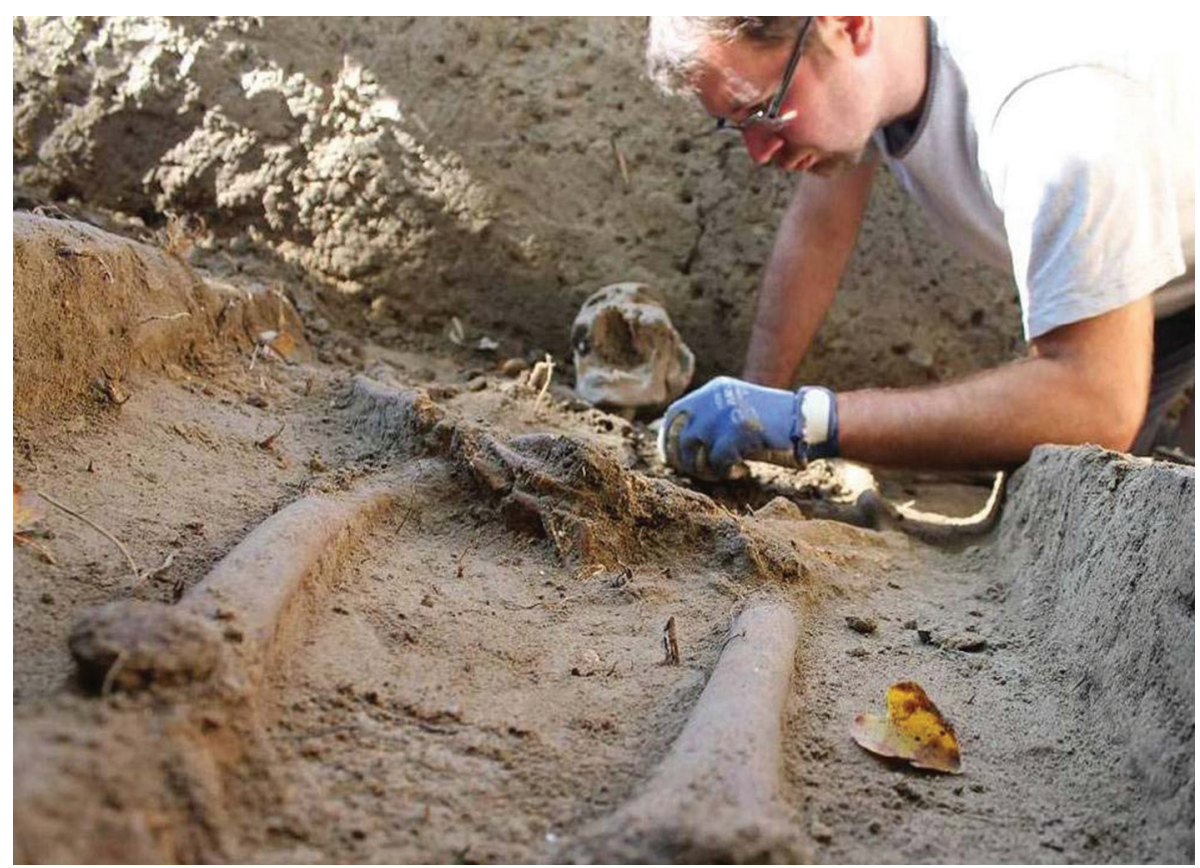

- Czech Science Foundation; Research into Historical Roads of Northwest Moravia and East Bohemia - National and Cultural Identity Programme, Ministry of Culture of the Czech Republic; Partnership in Research and Presentation of Archaeological Heritage (Figure 5) - ESF OP Education for Competitiveness (e.g. Šmejda 2014); Yamnaya Impact: Summer School, Archaeological Heritage and Research into European Population History - Visegrad Fund; Moravian Crossroads - National and Cultural Identity II Programme, Ministry of Culture of the Czech Republic. Encouraging results have proceeded from a project supported by the Olomouc Region entitled Preventive Archaeology: a project of preventive archaeological rescue excavations in the Olomouc Region reducing the damages caused by illegal use of metal detectors at archaeological sites (Figure 6). In cooperation with German institutions (Romano-Germanic Commission Frankfurt, University of Halle), it was possible to carry out a geophysical survey of many Neolithic and Early Bronze Age hill-top and fortified sites in Moravia (Figure 7). The cooperation culminated in joint research into an Early Bronze Age circular enclosure in Vřesovice in the Prostějov region - together with Martin Luther University of Halle-Wittenberg, Institute of Archaeological Heritage Brno, and Palacký University Olomouc (Daňhel

Figure 4. Archaeological Centre Olomouc, Ceramic laboratory. Photo: M. Bém.

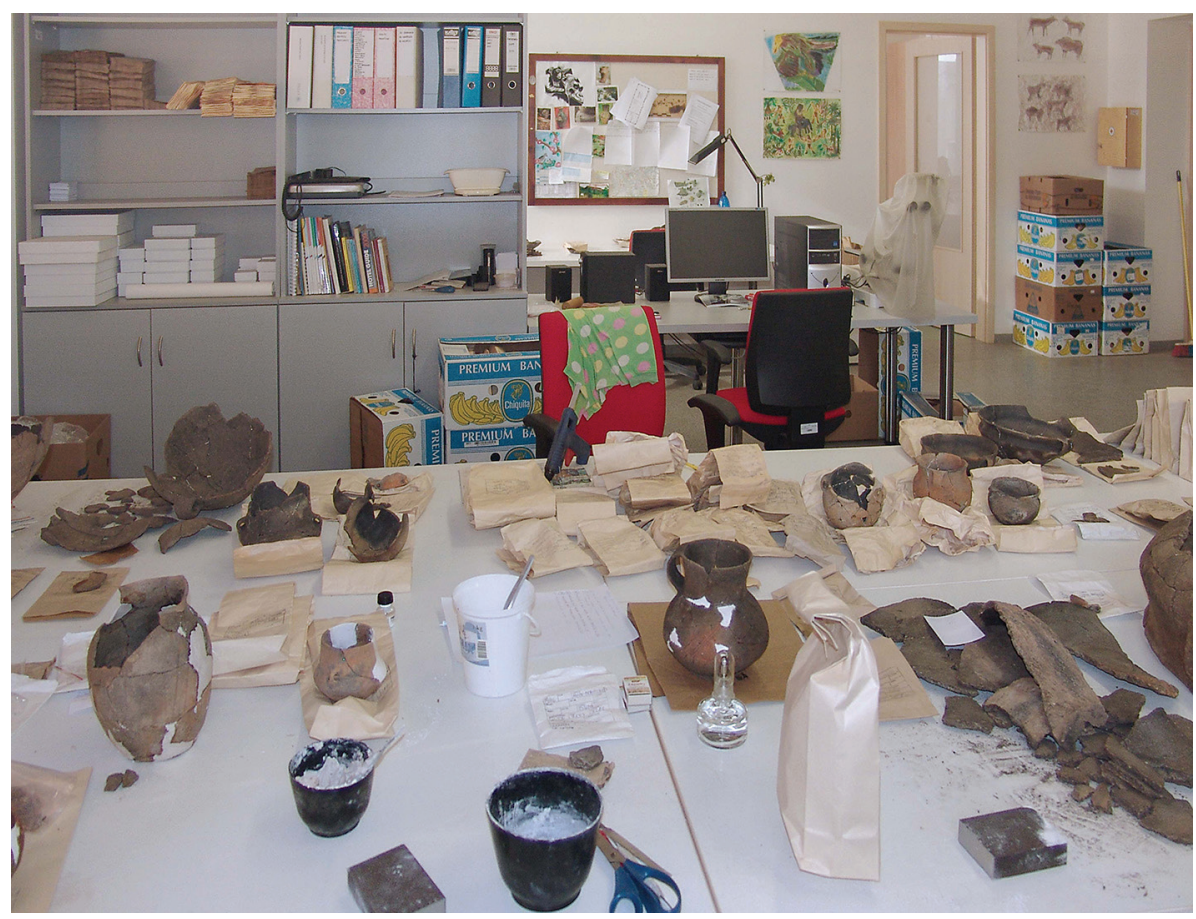




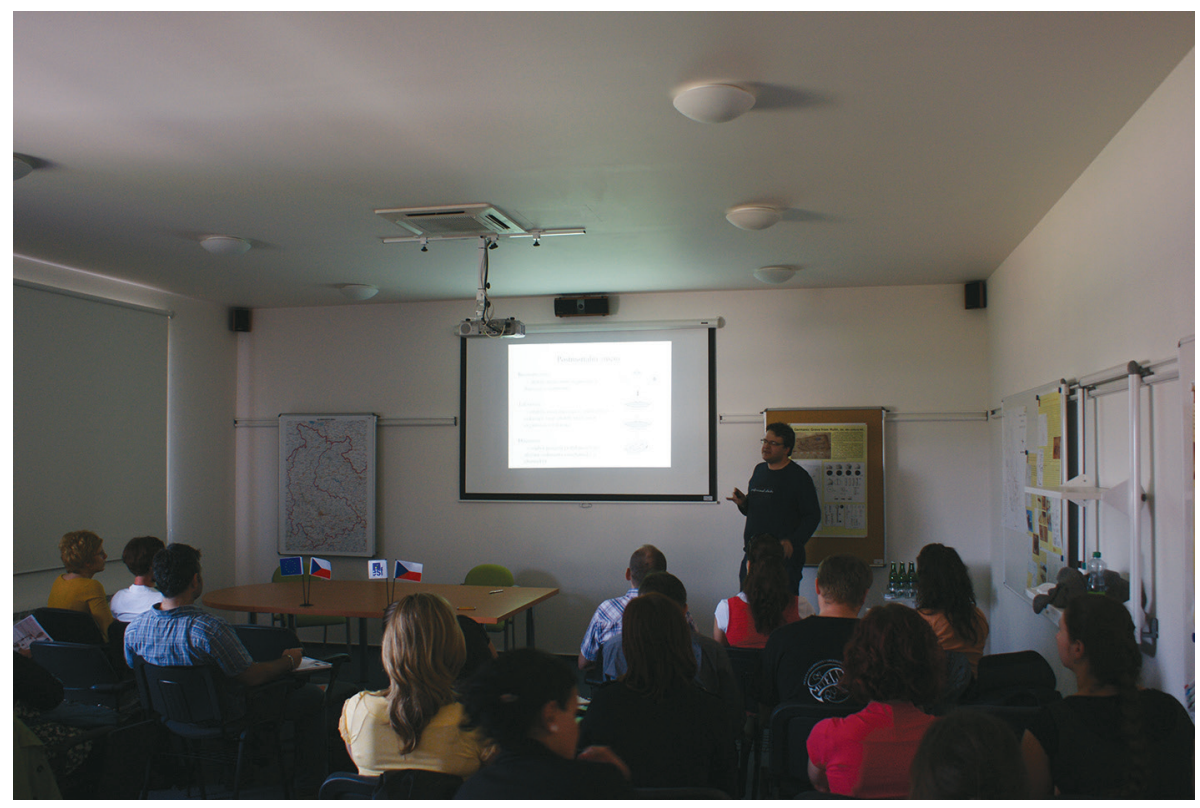

Figure 5. Lecture of Lubomír Prokeš at the workshop "Methods of Anthropology", $11^{\text {th }}$ $-12^{\text {th }}$ April 2013. Photo: L. Šín.

et al. 2015, Fojtík et al. 2016). Besides presentations at numerous domestic and foreign conferences, the research results are regularly presented to the non-professional public through educational lectures, and occasional or permanent exhibitions. There is a very wide and varied domestic and international cooperation with other archaeological and nature-scientific institutions including academic facilities. The closest cooperation is with the Palacký University Olomouc.

\section{Interdisciplinary approach sensu lato}

The above-mentioned specialized activities of the institution, along with publications and presentations, show that the professional working and research activity of ACO workers is focused on the interpretation of particular historical events in individual societies with the help of data obtained by archaeological excavations. The reconstruction of the life of a particular people (or small defined groups) living in the past is methodically based not only on descriptions of tangible archaeological evidence, i.e. not only on find contexts, their description and chronological classification. Tangible evidence represents only a partial element of social systems. Past societies - as components of ecosystems - can be detected not only on the basis of their material displays. Human populations - as particular cultural systems - must be assessed with regard to their interaction with the external environment. These interactions allow us to suppose the existence of stable adaptative mechanisms in historical societies, such as: applied settlement and subsistence strategies; technological strategies of the processing of particular materials; functional economic strategies; the diversification of society; and religious customs. Such a hypothesis, based on the existence of these mechanisms of adaptation, enables us to reconstruct the cultural displays of past societies. This method demands the application of the same theoretical approach equally in other disciplines. Using the standard methods of several disciplines enables an integral cooperation in studies of the settlement of particular regions in the past.

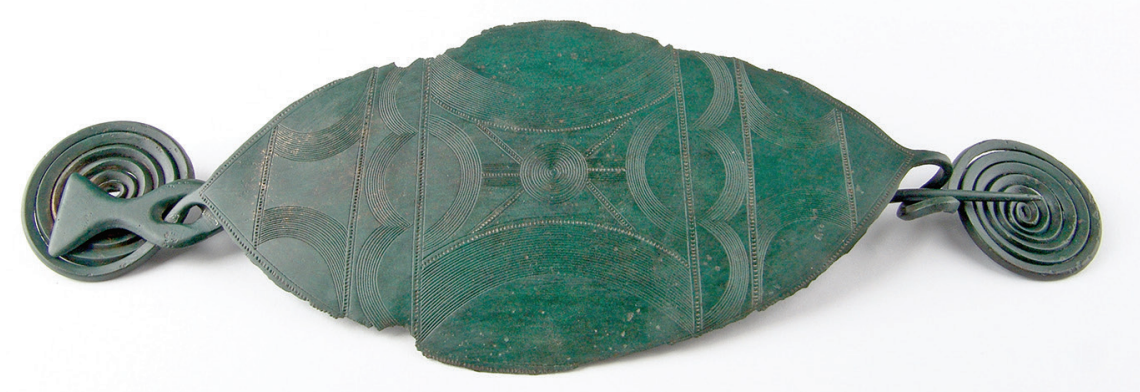

Figure 6. Shield fibula found with metal detector, site Nové Dvory - Náměšt’ na Hané (dist. Olomouc). Photo: M. Bém. 
Figure 7. Geophysical monitoring, site Bohuslavice u Kyjova (dist. Hodonín). Photo: M. Daňhel.

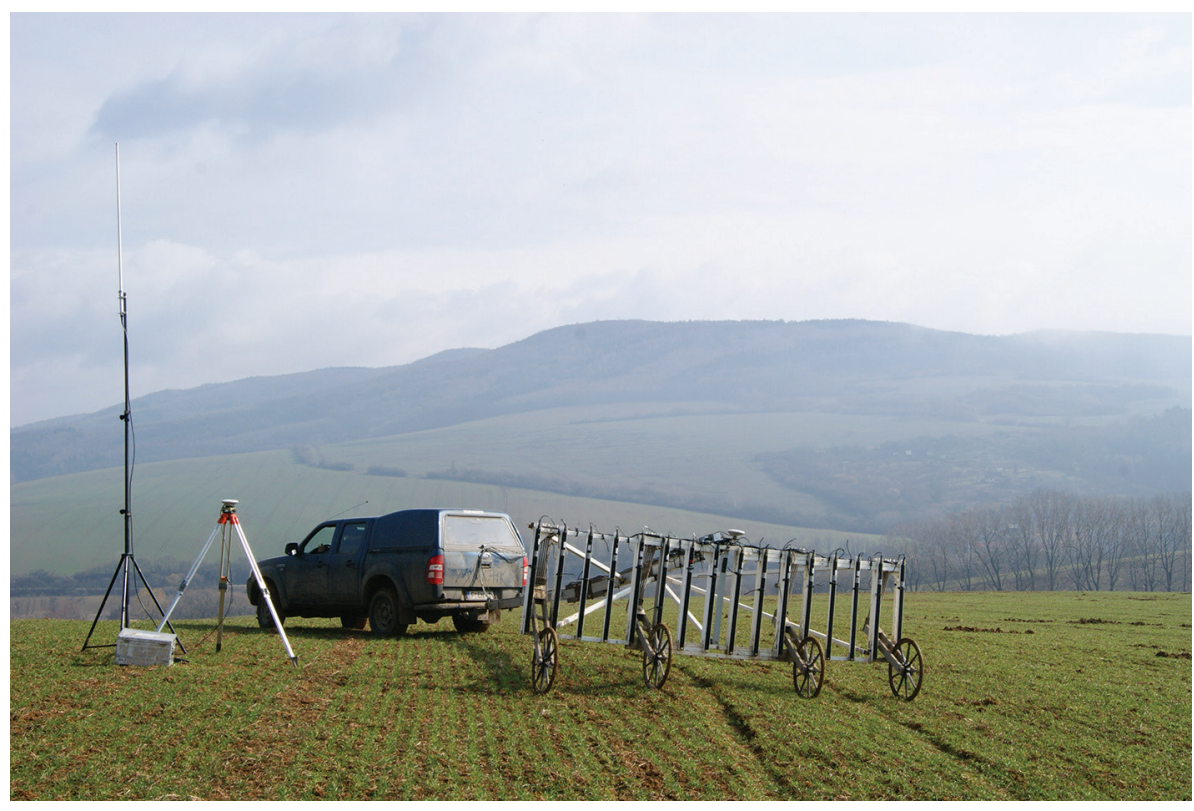

This discourse thus has to meet those criteria of interdisciplinary research, in particular on the basis of common values, conceptual definitions, methodological continuity and epistemology. Interdisciplinary approach is a counterweight to the ongoing specialization of disciplines. Such specialization can generate professional applications tailored to individual research subjects. However, the standard component of field research practice of $\mathrm{ACO}$ workers represents an integral cooperation with experts from other disciplines, mainly concerned with sampling at localities with archaeological excavations in progress. ACO offers the creation of a platform for interdisciplinary cooperation between experts from various disciplines concerning their direct cooperation in field research and the modelling of reconstruction procedures involving the settlement and funerary activities at individual localities.

\section{Interdisciplinary approach sensu stricto}

This interdisciplinary interconnection of excavations, technical and natural-scientific analyses, and conservation of artefacts, has enabled the identification of the negative imprints of leather on corroded bronze objects from the funerary equipment of Early Bronze Age graves unearthed in Hulín - U Isidorka (Peška at al. 2005; Peška at al. 2005a). This approach brought forth a perspective: the creation of a set of determined fingerprints of a particular prehistoric population. The find thus opened up the problem of previously applied methods of cleaning and conservation of bronze objects; namely that previous conservation irretrievably removed corrosion products together with any anthropogenic marks. New perspectives were also revealed by the confrontation of finger rings and the skeleton hand.

Figure 8. Prospecting and monitoring by aerial archaeology, site Jívová - Tepenec (dist. Olomouc). Photo: M. Kalábek.

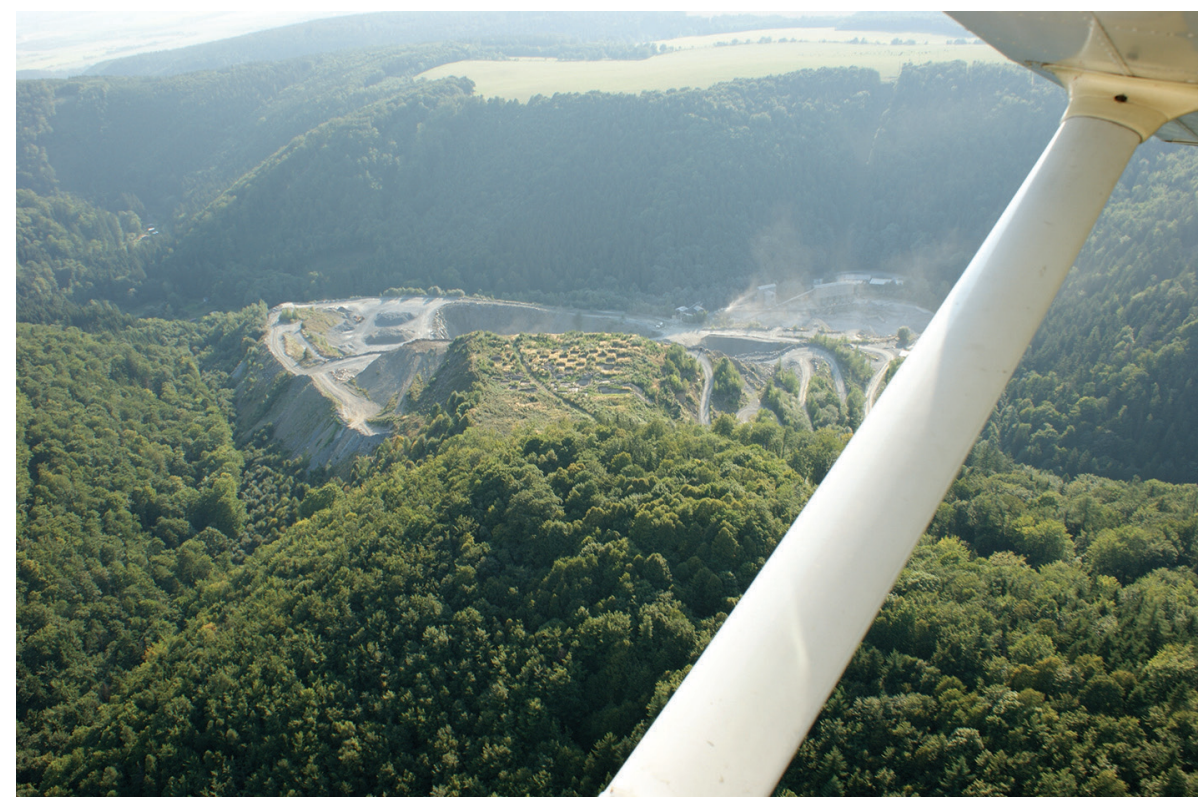


This approach was only possible when the excavation method used maintained the mutual relation between the components compared. Information was obtained which allows us to say that the deceased individuals bore finger rings during their lives. If the finger rings were only grave goods, then they were chosen thoroughly with regard to the size of the finger of the deceased person (Peška, Králík, Selucká 2006).

A methodical approach akin to that of forensic science was applied in the analysis of a grave context detected in Olomouc - Nemilany, Lidická Street (Nemilany 4 site) in 2005. The analyses were focused on a male inhumation burial dated to the period of the Corded Ware Culture. The burial was extraordinary not only for its unusually well-preserved skeletal remains but also regarding some aspects of the burial rites undertaken (the male was probably buried in a half-sitting position). The research also included the analysis and evaluation of some remnants of funerary equipment (animal bones, lithic and bone artifacts, boar tusks), the anthropological analysis of skeletal remains (sex diagnosis, estimation of age and stature, assessment of the state of health based on skeleton and dentition). The basic view was also extended by the analysis of dental microabrasions, which focused on the eating habits of this individual or on the way in which he used his dentition (probably also as a work tool), and by an anthropological reconstruction of their appearance based on the skull. The study was also enriched with usewear analysis of working marks on tools made from boar tusks, and a sex analysis based on aDNA (Králík at al. 2006; Urbanová et. al. 2007). This nearly exhaustive methodical approach has been applied generally by ACO workers within the process of the evaluation of field research results (e.g. Fialová at al. 2016; Jarošová at al. 2006; Peška, Králík 2013; Š́n, Vrána 2014). The close cooperation with experts in the field of geology, petroarchaeology, archaeozoology, use-wear analysis, analytical chemistry, anthropology, archaeobotany, palynology and others is the standard practice. The traditional method is already represented by intensive aerial surveys (Figure 8), particularly in central Moravia, which was upgraded recently by the use of laser images of the landscape (LIDAR). Chemical analyses of the infills of features and vessels have been carried out with increasing intensity and yielded many surprising results (milk and millet, fats and oils, pigments from bird excrements, etc.). Modern metallurgical research is motivated by the effort to reveal the secret of technological procedures and the origins of metals. The activity of the institution has also targeted the problem of absolute chronology, as exemplified by significant find contexts. New methods of analysing amber artefacts and raw amber have also come to the fore in an all-European context.

\section{Selected publications}

BÉM, M. at al. 2001: Archeologické zrcadlení. Archaeological reflections. Vlastivědné muzeum, Archeologické centrum, Olomouc.

DAŇHEL, M., FOJTÍK, P., NORTHE, A., PEŠKA, J. 2015: Vřesovice (k. ú Vřesovice u Prostějova, okr. Prostějov). Přehled výzkumů 56/1, 198-199.

FIALOVÁ, D., SKOUPÝ, R., DROZDOVÁ, E., KRZYŽÁNEK, V., ŠÍN, L., BEŇUŠ, R., KLÍMA, B. 2016: The Application of Scanning Electron Microscopy with Energy Dispersive X-ray Spectroscopy (SEM-EDX) in Ancient Dental Calculus for the Reconstruction of Human Habits. In: Microscopy and Microanalyses. Cambridge University Press 22, Supplement S3, New York, 2056-2057.

FOJTÍK, P., NORTHE, A., PEŠKA, J. 2016: Vřesovice (k. ú. Vřesovice u Prostějova, okr. Prostějov). Přehled výzkumu 57/1, 234-236.

JAROŠOVÁ, I., KRÁLÍK, M., NOVÁČEK, J., PEŠKA, J., TAJER, A. 2006 : Antropologické hodnocení tělesných pozůstatků jedince jevišovické kultury (?) z lokality Kroměřǐž 3 - Miňůvky, Křivky. In: Peška, J., Bém, M. (Eds.): Ročenka 2005. Archeologické centrum Olomouc, příspěvková organizace, Olomouc, 53-71.

KRÁLÍK, M., PEŠKA, J., KALÁBEK, M., URBANOVÁ, P., MOŘKOVSKÝ, T., JAROŠOVÁ, I., DRESLEROVÁ, G., NOVÁČEK, J., MALÁ, P., KRÁSNÁ, S. 2006: Předběžná analýza kosterních pozůstatků a hrobové výbavy jedince kultury lidu se šňůrovou keramikou z lokality Olomouce-Nemilan, ulice Lidická (Nemilany 4). In: Peška, J., Bém, M. (Eds.): Ročenka 2005. Archeologické centrum Olomouc, Olomouc, 108-145

PEŠKA, J. 2009: Protoúnětické pohřebiště z Pavlova. Archeologické centrum Olomouc, Olomouc.

PEŠKA, J., PLAČEK, M. 2002: Dědictví věků: nemovité archeologické památky Přerovska. Archeologické centrum Vlastivědného muzea, Olomouc.

PEŠKA, J., BERKOVEC, T., HLOŽEK, M., KRUPA, P., TROJEK, T., DROZDOVÁ, E., KOLDÍNSKÁ, Z., KRÁLÍK, M., SELUCKÁ, A. 2005: Dosavadní výsledky mezioborové spolupráce na nálezech ze starší doby bronzové v Hulíně - U Isidorka. In: Peška, J., Bém, M. (Eds.): Ročenka 2004. Archeologické centrum Olomouc, Olomouc, 68-93.

PEŠKA, J., HLOŽEK, M., KRÁLÍK, M., SELUCKÁ, A., RICHTROVÁ, A., PELÍŠKOVÁ, R. 2005a: Konzervace a materiálový průzkum kovových nálezů ze starší doby bronzové z Hulína - U Isidorka. In: Sborník z konference konzervátori̊ a restaurátorů, Plzen̆ 2005. Technické muzeum v Brně, Brno, 49-57.

PEŠKA, J., KRÁLÍK, M., SELUCKÁ, A. 2006: Rezidua a otisky organických látek v korozních produktech mědi a jejích slitin. Pilotní studie. Industrie starší doby bronzové. Památky archeologické 97, 5-46.

PEŠKA, J., KRÁLÍK, M. 2013: "Nagyrév Jugs" and Their Archaeological Context. In: Heyd, V., Kulcsár, G., Szeverényi, V. (Eds.): Transition to The Bronze Age - Interregional Interaction and Socio-Cultural Change in the Third Millenium BC Carpathian Basin and Neighbouring Regions. Archaeolingua Alapítvány, Budapest, 245-286.

ŠAFR, P. (Ed.) 2004: Popelnicová pole a doba halštatská: př́spěvky z VIII. konference, České Budějovice 22.-24. 9. 2004. Jihočeské muzeum, České Budějovice.

ŠÍN, L., VRÁNA, J. 2014: Charakter pohřebního ritu jako odraz událostí 19. století na střední Moravě. Český lid 101/2: 149-169.

ŠMEJDA, L. 2014: The Partnership in Research and Presentation of Archaeological Heritage. Interdisciplinaria Archaeologica. Natural Sciences in Archaeology V/2/2014, 163-170.

ŠUTEKOVÁ, J., PAVÚK P., KALÁBKOVÁ P., KOVÁR B. 2010: Panta rhei: studies on the chronology and cultural development of SouthEastern and Central Europe in Earlier prehistory prehistory presented to Juraj Pavúk on the Occasion of his $75^{\text {th }}$ Birthday. Comenius University in Bratislava. Studia archaeologica et Mediaevalia, Bratislava.

URBANOVÁ, P., PEŠKA, J., KALÁBEK, M., KRÁLÍK, M., MOŘKOVSKÝ, T., JAROŠOVÁ, I., HLOŽEK, M., DRESLEROVÁ, G., VAŇHAROVÁ, M., NOVÁČEK, J., KRÁSNÁ, S., MALÁ, P. 2007: Anthropological and archeological analysis of unique Eneolithic grave from Olomouc - Nemilany site, Czech Republic. Humanbiologia Budapestinensis 30, 37-44. 